\title{
Molecular identification of water molds (oomycetes) associated with chum salmon eggs from hatcheries in Japan and possible sources of their infection
}

\author{
Sakiko Orui Sakaguchi ${ }^{1} \cdot$ Gen Ogawa $^{2,3} \cdot$ Hiroaki Kasai $^{4} \cdot$ Yuichi Shimizu $^{2}$. \\ Hiroshi Kitazato $^{1} \cdot$ Katsunori Fujikura $^{1} \cdot$ Kiyotaka Takishita $^{1,5}$
}

Received: 14 October 2018 / Accepted: 5 July 2019 /Published online: 15 July 2019

(C) Springer Nature Switzerland AG 2019

\begin{abstract}
Oomycete infection of various freshwater animals, including salmonid eggs, causes significant economic damage to aquaculture worldwide. In this study, we detected oomycetes in infected chum salmon Oncorhynchus keta eggs at two hatcheries in northern Japan, in the source water used for egg incubation, and in the air at the hatcheries to clarify the source(s) of oomycete transmission using a DNA molecular marker. Seven oomycete taxa, belonging to Saprolegniaceae and Pythiaceae, were detected from the infected eggs. From the source water used for egg incubation and the air at the hatcheries, nine oomycete taxa, including those found on infected eggs, were detected, suggesting that both water and air are potential sources of oomycete transmission. There is no report of airborne transmission of these oomycetes detected in this study so far. Regarding protection and sterilization against oomycete infection in aquaculture hatcheries, not only water used at hatcheries but also the air in hatcheries may need to be considered hereafter.
\end{abstract}

Keywords Oomycetes $\cdot$ Chum salmon eggs $\cdot$ Saprolegniaceae $\cdot$ Pythiaceae $\cdot$ Internal transcribed spacer 2

Kiyotaka Takishita takishita@fwu.ac.jp

1 Japan Agency for Marine-Earth Science and Technology, 2-15 Natsushima, Yokosuka, Kanagawa 237-0061, Japan

2 Iwate Fisheries Technology Center, 3-75-3 Heita, Kamaishi, Iwate 026-0001, Japan

3 Present address: Iwate Prefectural Government Department of Agriculture, Forestry and Fisheries, 10-1 Uchimaru, Morioka, Iwate 020-8570, Japan

4 School of Marine Bioscience, Kitasato University, 1-15-1 Kitasato, Minami-ku, Sagamihara, Kanagawa 252-0373, Japan

5 Present address: International College of Arts and Sciences, Fukuoka Women's University, 1-1-1 Kasumigaoka, Higashi-ku, Fukuoka 813-8529, Japan 


\section{Introduction}

Water mold infection has a negative impact on freshwater fishes, amphibians, and their eggs, as well as crustaceans, and is caused by oomycetes (Fisher et al. 1975; Noga 1993; Densmore and Green 2007; Phillips et al. 2008; Fernández-Benéitez et al. 2011; Bruno et al. 2013). Particularly, the major pathogens causing infection in fishes and their eggs are Saprolegniaceae belonging to oomycetes, such as Saprolegnia, Achlya, and Aphanomyces (Hatai 1980; van den Berg et al. 2013). Among the Saprolegniaceae, Saprolegnia diclina and S. parasitica are thought to cause significant damage to salmon hatcheries (van den Berg et al. 2013). In fact, economic losses to hatcheries because of Saprolegnia infections reach 10-50\% worldwide (Phillips et al. 2008). In addition, the mortality of fish larvae caused by Pythium, belonging to the other oomycete family Pythiaceae, has also been reported in Japan (Miura et al. 2010).

To treat oomycete infection, malachite green was used in salmon hatcheries, but negative effects of malachite green have also been reported, such as the persistence of the medicine and carcinogenic effects on the organs of the treated fishes and their eggs. Thus, the use of malachite green has been banned worldwide since 2000 to ensure food hygiene (Miura et al. 2005; Sudova et al. 2007; Phillips et al. 2008). Some alternative chemical agents, such as bronopol, formalin, and hydrogen peroxide have been examined, but show lower effectiveness against water mold compared to malachite green and toxicity problems (Braidwood 2000; Ali et al. 2015). Therefore, in some chum salmon Oncorhynchus keta hatcheries in Japan, the staff manually removes the infected eggs individually.

Most hatcheries in Iwate Prefecture, northern Japan, were seriously damaged by the Great East Japan Earthquake and Tsunami on March 11, 2011. The number of released juvenile chum salmon decreased to 66\%, and that of the returned chum salmon in 2011 and 2012 decreased to approximately $50 \%$ of that before the event (Ogawa 2014). In addition to the decreased numbers of eggs for artificial hatching because of the reduced number of returning adults, frequent water mold infection of eggs in hatcheries occurs in this area. However, little is known about the diversity of oomycetes causing water mold infection, as well as the possible sources of infection (such as water or air) in these hatcheries.

Oomycetes in salmon hatcheries are traditionally identified based on morphological observation (Kitancharoen et al. 1997; Hussein et al. 2001). However, molecular techniques using DNA markers, such as internal transcribed spacers (ITSs) of ribosomal RNA genes, have recently been used in many countries other than Japan (Lévesque and De Cock 2004; DiéguezUribeondo et al. 2009; Eissa et al. 2013; Sandoval-Sierra et al. 2014a, b). In the present study, using molecular techniques, the diversity and source of water molds infecting salmon eggs in hatcheries in northern Japan were investigated.

\section{Materials and methods}

\section{Collection of chum salmon eggs and environmental samples from hatcheries}

Approximately 30 eggs of chum salmon Oncorhynchus keta infected with water mold were collected from incubation water tanks at two chum salmon hatcheries in the Iwate Prefecture, northern Japan: Hatchery A on December 24, 2014, November 19, 2015, and January 7, 2016 and Hatchery B on November 25, 2014, January 13, 2015, November 20, 2015, and January 8, 2016 (Table 1). To investigate the source(s) of water mold infection in these hatcheries, $4 \mathrm{~L}$ of 
source water used for egg incubation on November 19, 2015 and January 7, 2016 at Hatchery A and on November 20, 2015 and January 8, 2016 at Hatchery B were collected. The water was from well or ground (fresh) water. In addition, $4 \mathrm{~L}$ distilled water in a bucket without a cover was left for 2 weeks near the egg incubation tanks to evaluate the possibility of aerial infection. The temperature of the source water used for egg incubation was measured at the time of the sample collection. The collected eggs and water were stored at $-80{ }^{\circ} \mathrm{C}$ and $4{ }^{\circ} \mathrm{C}$, respectively.

\section{Cultivation of oomycetes}

Half (2 L) of each of the source water samples used for egg incubation and the water left for 2 weeks was concentrated to approximately $50 \mathrm{~mL}$ using a $0.22-\mu \mathrm{m}$ filter. To cultivate oomycetes from these samples, sterilized hemp seeds as bait for oomycetes were added to each water sample in Petri dishes (Diéguez-Uribeondo et al. 2007). The hemp seed cultures were incubated for 2 weeks at 5,10 , and/or $15{ }^{\circ} \mathrm{C}$ based on the temperatures of incubation water tank at hatcheries A and B shown in Table 1. Hemp seeds covered by colonies of oomycetes were preserved at $-80{ }^{\circ} \mathrm{C}$.

\section{Sequencing}

Genomic DNA was extracted from the water molds associated with eggs in the incubation tanks of the hatcheries and with hemp seeds in the cultures using a DNeasy Plant Mini kit (Qiagen, Hilden, Germany) according to the manufacturer's instructions. To determine the quality of the extracted DNA, the bacterial 16S rRNA and eukaryotic 18S rRNA genes were amplified using the universal primers $16 \mathrm{~S}$ B27F (5'-AGAGTTTGATCCTGGCTCAG-3')/16S U1492R (5'-GGTTACCTTGTTACGACTT-3') (Weisburg et al. 1991) and 18SF (5'-AACC TGGTTGATCCTGCCAG-3')/18SR (5'-AACCTGGTTGATCCTGCCAG-3') (Ota et al. 2009), respectively. Next, the ITS 2 region of ribosomal RNA genes (ITS2) was PCRamplified with the oomycete-specific primers Oom-Up5.8S (5'-TGCGATACGTAATG CGAATT-3') and Oom-Lo28S (5'-ACTTGTTCGCTATCGGTCTCGCA-3') (Tambong et al. 2006; Liu et al. 2014). The PCR was performed using TaKaRa Ex Taq (TaKaRa, Shiga, Japan) or HotStarTaq (Qiagen) under the following conditions: $30-40$ cycles of denaturation at $94{ }^{\circ} \mathrm{C}$

Table 1 Collection data of chum salmon eggs and environmental samples at two hatcheries. "White circle" indicates obtained samples

\begin{tabular}{|c|c|c|c|c|c|}
\hline & \multirow{2}{*}{$\begin{array}{l}\text { Date of } \\
\text { collection }\end{array}$} & \multirow{2}{*}{$\begin{array}{l}\text { Water tank temperature } \\
\left({ }^{\circ} \mathrm{C}\right)\end{array}$} & \multicolumn{3}{|c|}{ Type of samples } \\
\hline & & & $\begin{array}{l}\text { Infected } \\
\text { eggs }\end{array}$ & $\begin{array}{l}\text { Water used for egg incubation } \\
\text { in tank }\end{array}$ & $\begin{array}{l}\text { Air in } \\
\text { hatchery }\end{array}$ \\
\hline \multirow{3}{*}{$\begin{array}{l}\text { Hatchery } \\
\text { A }\end{array}$} & Dec. 24,2014 & 6.0 & ० & & \\
\hline & Nov. 19, 2015 & 12.7 & $\circ$ & ० & ० \\
\hline & Jan. 7, 2016 & 7.8 & $\circ$ & ० & $\circ$ \\
\hline \multirow{4}{*}{$\begin{array}{l}\text { Hatchery } \\
\text { B }\end{array}$} & Nov. 25, 2014 & 14.7 & $\circ$ & & \\
\hline & Jan. 13, 2015 & 11.5 & ० & & \\
\hline & Nov. 20, 2015 & 15.2 & ० & ० & ○ \\
\hline & Jan. 8, 2016 & 12.8 & ० & o & ० \\
\hline
\end{tabular}

${ }^{a}$ Water samples left for 2 weeks near the incubation tank of each hatchery were investigated 
for $30 \mathrm{~s}$, annealing at $55^{\circ} \mathrm{C}$ for $30 \mathrm{~s}$, and extension at $72{ }^{\circ} \mathrm{C}$ for $1 \mathrm{~min}$. The PCR products obtained, approximately 800-900 bp in size, were cloned into the pCR4-TOPO vector using the TOPO TA Cloning Kit (Invitrogen, Carlsbad, CA, USA) or pGEM T Easy using the pGEM T Easy system (Promega, Madison, WI, USA). The resulting clones were sequenced with a 3730xl Genetic Analyzer DNA AutoSequencer (Applied Biosystems, Foster City, CA, USA) using the BigDye Terminator v3.1 Cycle Sequencing Kit (Applied Biosystems) according to the manufacturer's instructions. The obtained sequences were subjected to blast searches. In addition, obtained Saprolegnia sequences were checked as described by Sandoval-Sierra et al. (2014b), in which Saprolegnia species with misidentified names in public DNA databases were carefully assessed by phylogenetic analyses.

\section{Phylogenetic analyses}

The ITS2 region sequences of oomycetes detected in this study were separately aligned with the corresponding sequences from phylogenetically diverse Saprolegniaceae and Pythiaceae using MEGA 7 (Kumar et al. 2016) and MAFFT (Katoh and Standley 2013). The alignments of Saprolegniaceae and Pythiaceae were trimmed by removing ambiguously aligned regions using trimAl version 1.3 with the option "automated1" (Capella-Gutiérrez et al. 2009). The maximum likelihood (ML) phylogenetic trees and corresponding bootstrap support values (1000 replicates) were calculated using MEGA 7 software for the resulting datasets (40 taxa/ 419 positions for Saprolegniaceae and 34 taxa/682 positions for Pythiaceae). Initial trees for the heuristic search were obtained automatically by applying the neighbor joining and BioNJ algorithms to a matrix of pairwise distances estimated using the maximum composite likelihood approach, and then selecting the topology with the superior log-likelihood. For these datasets, Bayesian analyses were performed using MrBayes v3.2.5 (Ronquist et al. 2012). Six parallel metropolis-coupled Markov chain Monte Carlo (MCMCMC) runs, each consisting of three heated chains and one cold chain with default chain temperatures, were run for 1,000,000 generations. Log-likelihood scores and trees with branch lengths were sampled every 1000 generations. The first 250,000 generations were excluded as burn-in, and the remaining trees were summarized to obtain Bayesian posterior probabilities. Convergence of parallel MCMCMC runs was judged by the average SD of split frequencies. For both ML and Bayesian analyses, the most appropriate models selected with PhyML 3.0 (Lefort et al. 2017) were applied. The sequences detected in this study showing identity of more than $98 \%$ with those of described species were identified at the species level. The sequences determined in this study were deposited into the DDBJ/EMBL/GenBank databases under accession nos. LC369091-LC369095, LC369097-LC369099, and LC369101-LC369103.

\section{Results}

\section{Identification by phylogenetic analyses}

Phylogenetic analyses of the Saprolegniaceae sequences determined in this study revealed four taxa of the genus Saprolegnia (S. australis, S. diclina, S. ferax, and S. parasitica) and one taxon of the genus Aphanomyces (A. laevis) at the species level, while two taxa of the genus Saprolegnia and one taxon of genus Leptolegnia were not identified at the species level (hereafter, referred to as Saprolegnia sp. 1, Saprolegnia sp. 2, and Leptolegnia sp. 1, 
respectively) (Fig. 1). Among Pythiaceae, one taxon of the genus Pythium (P. monospermum) was identified at the species level, while two taxa of this genus were not identified at the species level (hereafter, referred to as Pythium sp. 1 and Pythium sp. 2) (Fig. 2).

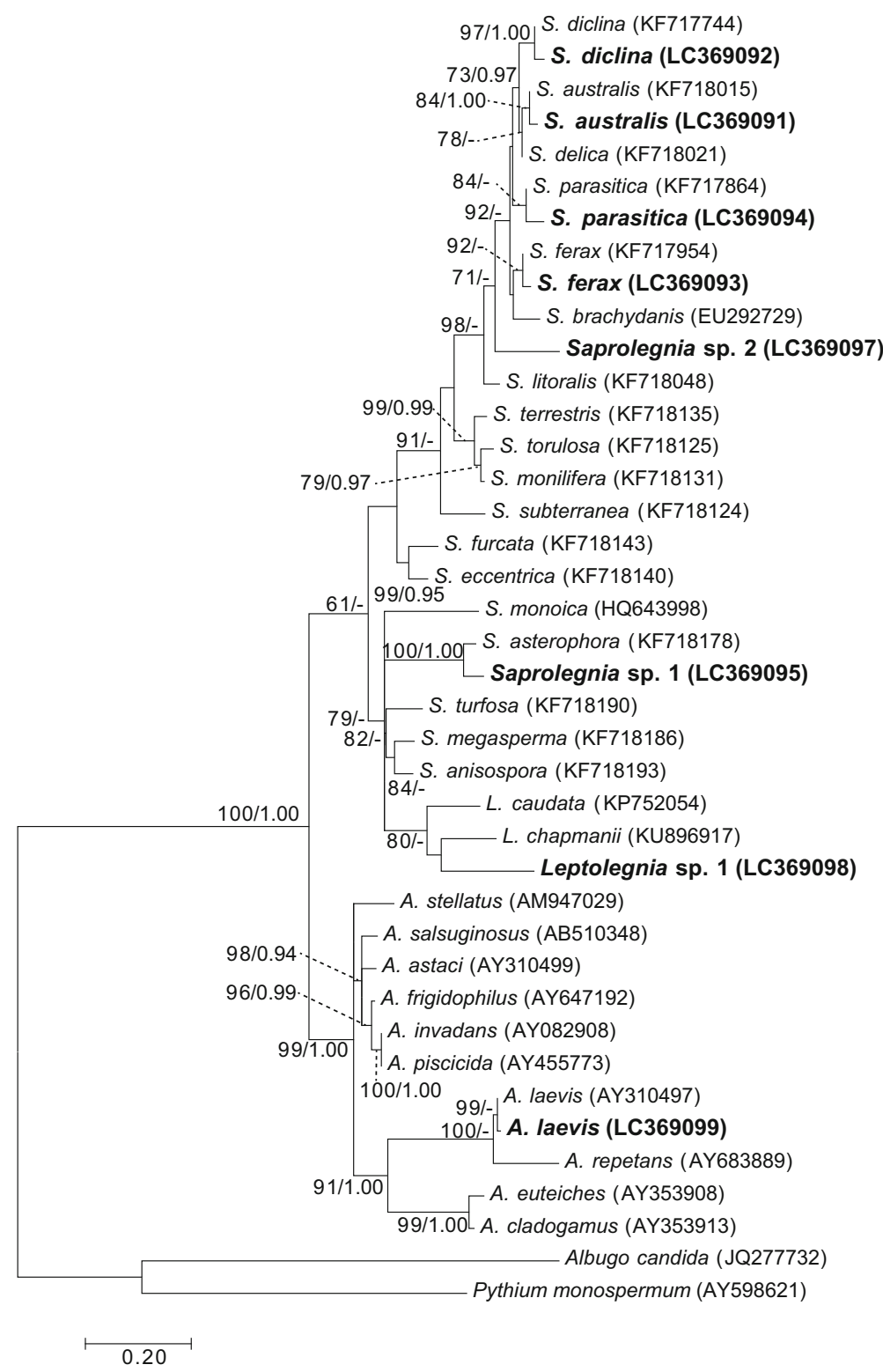

Fig. 1 Maximum likelihood (ML) phylogeny of internal transcribed spacer 2 region of ribosomal RNA genes from Saprolegniaceae (Saprolegnia, Leptolegnia, and Aphanomyces). Pythium monospermum (Pythiaceae) and Albugo candida (Albuginaceae) were used as outgroups to root the tree. ML bootstrap probabilities and Bayesian posterior probabilities for bipartitions with over $65 \%$ and 0.90 support, respectively, are shown. Sequences determined in this study are shown in bold. DDBJ/ EMBL/GenBank databases accession numbers are shown in parentheses 


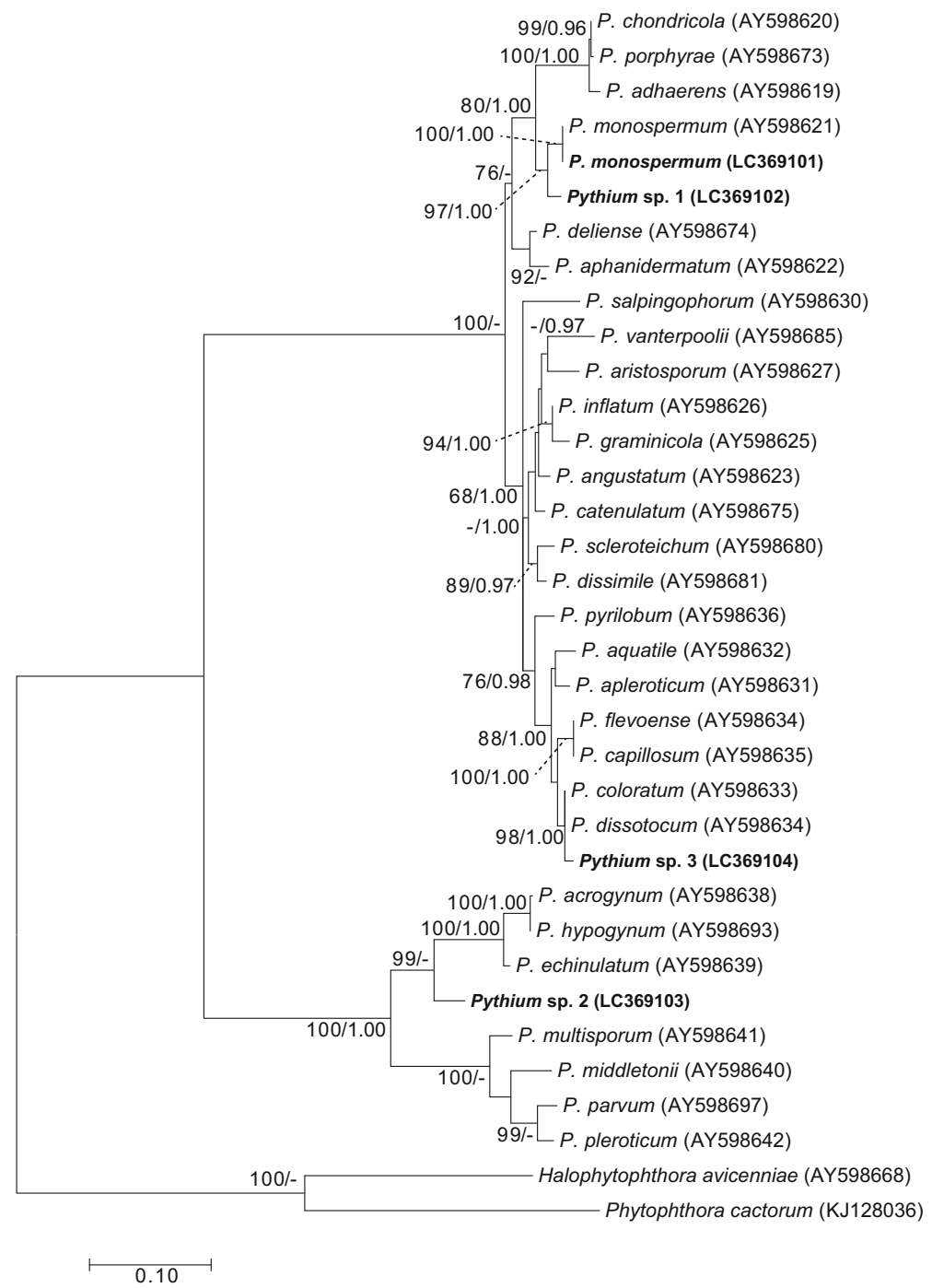

Fig. 2 Maximum likelihood (ML) phylogeny of internal transcribed spacer 2 region of ribosomal RNA genes from Pythiaceae. Halophytophthora avicenniae (Pythiaceae) and Phytophthora cactorum (Pythiaceae) were used as outgroups to root the tree. ML bootstrap probabilities and Bayesian posterior probabilities for bipartitions with over $65 \%$ and 0.90 support, respectively, are shown. Sequences determined in this study are shown in bold. $\mathrm{DDBJ} / \mathrm{EMBL} / \mathrm{GenBank}$ databases accession numbers are shown in parentheses

\section{Oomycetes associated with infected eggs at the hatcheries}

In Hatchery A, two Saprolegniaceae taxa and three Pythiaceae taxa were identified from the infected eggs (Table 2). Saprolegnia sp. 1 was detected in December 2014, November 2015, and January 2016 samples. Aphanomyces laevis and Pythium sp. 1 were detected in December 2014. Pythium monospermum was found in November 2015. Pythium sp. 1 and Pythium sp. 2 were identified in January 2016. In Hatchery B, three Saprolegniaceae taxa and two Pythiaceae taxa were detected from the infected eggs. Saprolegnia parasitica was detected in November 
2014. Pythium monospermum and Pythium sp. 1 were identified in January 2015, while P. monospermum was detected in November 2015. Saprolegnia ferax and A. laevis were found in January 2016.

\section{Oomycetes associated with water used for egg incubation in tank and water left for 2 weeks}

In Hatchery A, six taxa (S. australis, S. ferax, Saprolegnia sp. 1, Saprolegnia sp. 2, Pythium sp. 1, and Pythium sp. 2) were detected from hemp seed cultures at $5^{\circ} \mathrm{C}$ with tank water used for egg incubation in January 2016 (Table 3). From the hemp seed cultures at $5{ }^{\circ} \mathrm{C}$ and $10^{\circ} \mathrm{C}$ with water left for 2 weeks near the incubation tanks, nine taxa $(S$. australis, $S$. diclina, S. ferax, S. parasitica, Saprolegnia sp. 1, Saprolegnia sp. 2, Leptolegnia sp. 1, Pythium sp. 1, and Pythium sp. 2) were detected at Hatchery A in January 2016. Saprolegnia sp. 2 and Pythium sp. 1 were found only from the hemp seed culture at $5{ }^{\circ} \mathrm{C}$, while $S$. diclina, S. ferax, S. parasitica, and Leptolegnia sp. 1 were found only from the culture at $10^{\circ} \mathrm{C}$. At Hatchery B, one taxon (Saprolegnia sp. 2) was detected from hemp seed cultures at $15{ }^{\circ} \mathrm{C}$ with water used for egg incubation from the tank in November 2015. One taxon ( $S$. ferax) and five taxa (S. australis, S. diclina, S. ferax, S. parasitica, and Leptolegnia sp. 1) were detected from the hemp seed culture at $15{ }^{\circ} \mathrm{C}$ with water left for 2 weeks in November 2015 and from that at $10{ }^{\circ} \mathrm{C}$ in January 2016 at Hatchery B, respectively.

\section{Discussion}

In this study, Saprolegnia ferax, S. parasitica, Aphanomyces laevis, and Pythium monospermum were identified from eggs infected by water molds. These species, except for A. laevis, were previously reported to infect eggs of salmonid fishes at Japanese hatcheries (Kitancharoen et al. 1997). A. laevis often occurs as a dominant species in Japanese lake water (Suzuki 1960), but this species was also found on eggs of a salmonid fish in Poland (Czeczuga et al. 2005).

In the present study, the sequences of not only Saprolegniaceae taxa but also Pythiaceae taxa (P. monospermum and Pythium sp.1) were frequently recovered. Kitancharoen et al.

Table 2 Oomycetes species detected from chum salmon eggs infected with water mold. "+" and "-" indicate detected and undetected, respectively

\begin{tabular}{|c|c|c|c|c|c|c|c|}
\hline & \multicolumn{3}{|c|}{ Hatchery A } & \multicolumn{4}{|c|}{ Hatchery B } \\
\hline & $\begin{array}{l}\text { Dec. } 24 \text {, } \\
2014\end{array}$ & $\begin{array}{l}\text { Nov. 19, } \\
2015\end{array}$ & $\begin{array}{l}\text { Jan. } 7 \\
2016\end{array}$ & $\begin{array}{l}\text { Nov. } 25 \text {, } \\
2014\end{array}$ & $\begin{array}{l}\text { Jan. 13, } \\
2015\end{array}$ & $\begin{array}{l}\text { Nov. } 20 \text {, } \\
2015\end{array}$ & $\begin{array}{l}\text { Jan. 8, } \\
2016\end{array}$ \\
\hline Saprolegnia ferax & - & - & - & - & - & - & + \\
\hline S. parasitica & - & - & - & + & - & - & - \\
\hline Saprolegnia sp. 1 & + & + & + & - & - & - & - \\
\hline $\begin{array}{l}\text { Aphanomyces } \\
\text { laevis }\end{array}$ & + & - & - & - & - & - & + \\
\hline $\begin{array}{l}\text { Pythium } \\
\quad \text { monospermum }\end{array}$ & - & + & - & - & + & + & - \\
\hline Pythium sp. 1 & + & - & + & - & + & - & - \\
\hline Pythium sp. 2 & - & - & + & - & - & - & - \\
\hline
\end{tabular}


Table 3 Oomycetes species detected from environmental samples in hatcheries and chum salmon eggs. "+" and "_" indicate detected and undetected, respectively

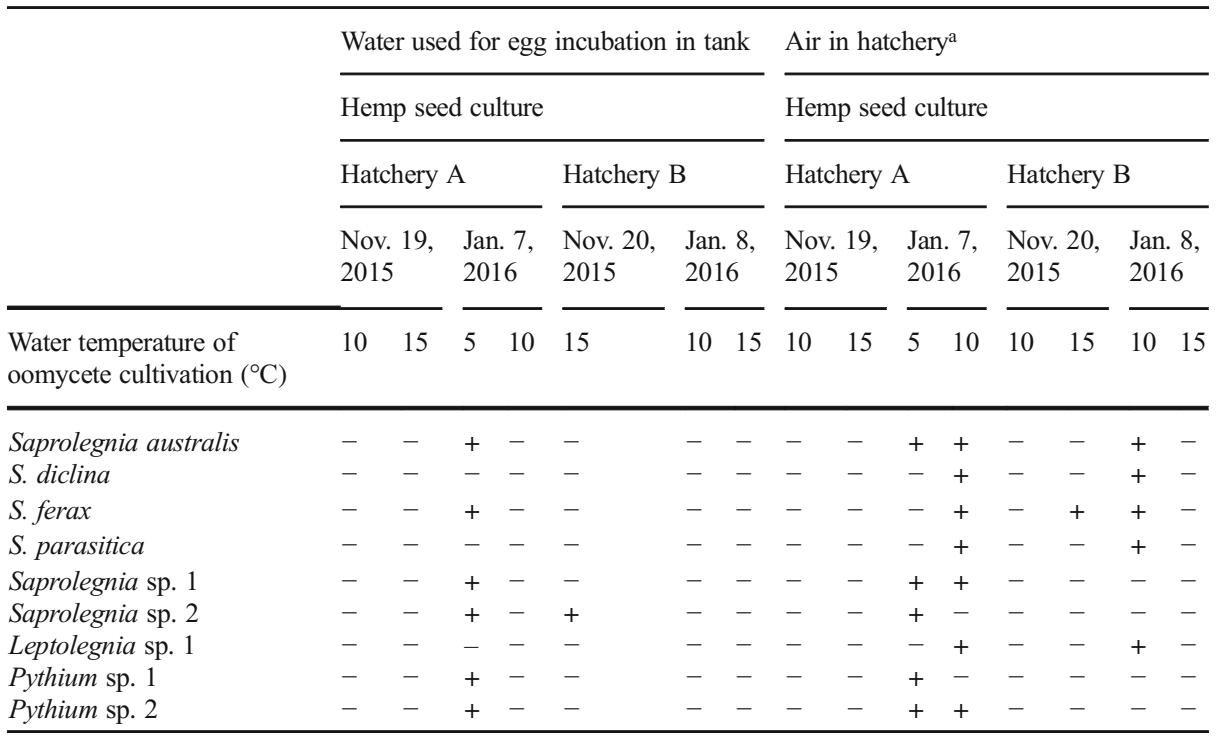

${ }^{a}$ Water samples left for 2 weeks near the incubation tank of each hatchery were investigated

(1997) reported that the genus Saprolegnia, Leptolegnia, and Achlya of the Saprolegniaceae family were dominant, while the genus Pythium was not dominant on infected eggs of salmonid fishes. Czeczuga et al. (2014) also rarely found P. monospermum on eggs from a salmonid fish in Poland. However, based on our findings, oomycetes other than Saprolegniaceae such as P. monospermum dominantly colonized when no Saprolegniaceae species were present (see infected eggs of Hatchery B). It remains unclear which environmental factors, such as water temperature, are significantly related to the occurrence of Pythium and Saprolegniaceae species.

Among the oomycete taxa detected from the infected eggs, sequences of $S$. ferax, S. parasitica, Saprolegnia sp. 1, Pythium sp. 1, and Pythium sp. 2 were retrieved from the water used for egg incubation in the tanks and water left near the incubation tanks at both hatcheries. These findings suggest that both water for egg incubation and air are sources of water mold transmission. Regarding airborne transmission, in oomycete species infecting to terrestrial plant (such as Peronospora tabacina and Phytophthora infestans), aerial dispersion of their zoospores has been reported (Aylor 2003; Glais et al. 2014), like bacteria and fungi (Yanong and Erlacher-Reid 2012). Although there is no report about the airborne transmission of oomycete species detected in this study, it is possible that the zoospores of water molds infecting salmon eggs can also float in the air as aerosols.

In salmonid hatcheries, water used for incubation is known to be a source of oomycete invasion (Bruno et al. 2011). To prevent invasion from this route, disinfection of the water for incubation has been attempted by ultraviolet (UV) light, ozone, and hydrogen peroxide (Heikkinen et al. 2013). Markedly, UV irradiation experiments performed by Vlasenko (1969) and Kimura et al. (1980) showed that zoospores of oomycetes (Saprolegnia) were more sensitive than their hyphae. Based on the results found in the present study, it is highly likely that the air in hatcheries, as well as the water for incubation, is a route of oomycete invasion. In public human health, to reduce airborne disease transmission by bacteria and 
spores of fungi, the effectiveness of UV air filters and air ultraviolet germicidal irradiation (UVGI) in the indoor environment has been reported (Kujundzic et al. 2006, 2007; Xu et al. 2011; Kim and Kang 2018). Thus, such treatments could also be applied to control the possible airborne transmission of oomycete zoospores in hatcheries, which may be a new viewpoint to address the problem of oomycete infection.

The sequences of Pythium monospermum and A. laevis detected from the infected eggs were not recovered from the source water used for egg incubation and water left near the incubation tank. These species may be very rare in our samples for analyzing the infection sources. Otherwise, we cannot completely exclude the possibility that these two taxa were transmitted by artificial contamination at the time of egg collection (Yanong and Erlacher-Reid 2012).

Acknowledgments We thank the staffs of the two salmon hatcheries for their help with sample collection and Ms. Midori Hagio for DNA analyses.

Funding information This study was supported by the research project Tohoku Ecosystem-Associated Marine Sciences from the Ministry of Education, Culture, Sports, Science, and Technology.

\section{Compliance with ethical standards}

Conflict of interest The authors declare that they have no conflict of interest.

Ethical approval All applicable international, national, and/or institutional guidelines for the care and use of animals were followed by the authors.

\section{References}

Ali SE, Evensen Ø, Skaar I (2015) Recent advances in the mitigation of Saprolegnia infections in freshwater fish and their eggs. In: Méndez-Vilas A (ed) The battle against microbial pathogens: basic science, technological advances and educational programs. Formatex Research Center, Badajoz, pp 691-697

Aylor D (2003) Spread of plant disease on a continental scale: role of aerial dispersal of pathogens. Ecology 84: 1989-1997

Braidwood JC (2000) Use of bronopol for the treatment of diseases in fish. Vericore Limited, Basingstoke

Bruno DW, van West P, Beakes GW (2011) Saprolegnia and other oomycetes. In: Woo PTK, Bruno DW (eds) Fish diseases and disorders. Volume 3: viral, bacterial and fungal infections. CABI Publishing, Wallingford, pp 669-720

Bruno DW, Noguera P, Poppe T (2013) Fungal and related oomycete infections. In: A Colour Atlas of Salmonid Diseases. Springer, Dordrecht, pp 99-106

Capella-Gutiérrez S, Silla-Martínez JM, Gabaldón T (2009) trimAl: a tool for automated alignment trimming in large-scale phylogenetic analyses. Bioinformatics 25:1972-1973

Czeczuga B, Bartel R, Kiziewicz B, Godlewska A, Muszyńska E (2005) Zoosporic fungi growing on the eggs of sea trout (Salmo trutta m. trutta L.) in river water of varied trophicity. Pol J Environ Stud 14:295-303

Czeczuga B, Semeniuk A, Czeczuga-semeniuk E (2014) Effect of trophically different water bodies on the straminipilous fungal infection of Stenodus genus (Coregoninae) eggs. Afr J Microbiol Res 8:503-510

Densmore CL, Green DE (2007) Diseases of amphibians. ILAR J 48:235-254

Diéguez-Uribeondo J, Fregeneda-Grandes JM, Cerenius L, Pérez-Iniesta E, Aller-Gancedo JM, Tellería MT, Söderhäll K, Martín MP (2007) Re-evaluation of the enigmatic species complex Saprolegnia diclinaSaprolegnia parasitica based on morphological, physiological and molecular data. Fungal Genet Biol 44: 585-601

Diéguez-Uribeondo J, García MA, Cerenius L, Kozubíková E, Ballesteros I, Windels C, Weiland J, Kator H, Söderhäll K, Martín MP (2009) Phylogenetic relationships among plant and animal parasites, and saprotrophs in Aphanomyces (Oomycetes). Fungal Genet Biol 46:365-376 
Eissa AE, Abdelsalam M, Tharwat N, Zaki M (2013) Detection of Saprolegnia parasitica in eggs of angelfish Pterophyllum scalare (Cuvier-Valenciennes) with a history of decreased hatchability. Int J Vet Sci Med 1:714

Fernández-Benéitez MJ, Ortiz-Santaliestra ME, Lizana M, Diéguez-Uribeondo J (2011) Differences in susceptibility to Saprolegnia infections among embryonic stages of two anuran species. Oecologia 165:819-826

Fisher WS, Nilson EH, Shleser RA (1975) Effect of the fungus Haliphthoros milfordensis on the juvenile stages of the American lobster Homarus americanus. J Invertebr Pathol 26:41-45

Glais I, Montarry J, Corbière R, Pasco C, Marquer B, Magalon H, Andrivon D (2014) Long-distance gene flow outweighs a century of local selection and prevents local adaptation in the Irish famine pathogen Phytophthora infestans. Evol Appl 7:442-452

Hatai K (1980) Saprolegniasis in salmonids. Fish Pathol 14:199-206 [in Japanese with English abstract]

Heikkinen J, Mustonen SM, Eskelinen P, Sundberg LR, von Wright A (2013) Prevention of fungal infestation of rainbow trout (Oncorhynchus mykiss) eggs using UV irradiation of the hatching water. Aquac Eng 55:9-15

Hussein MM, Hatai K, Nomura T (2001) Saprolegniosis in salmonids and their eggs in Japan. J Wildl Dis 37 : 204-207

Katoh K, Standley DM (2013) MAFFT multiple sequence alignment software version 7: improvements in performance and usability. Mol Biol Evol 30:772-780

Kim DK, Kang DH (2018) UVC-LED irradiation effectively inactivates aerosolized viruses, bacteria, and fungi in a chamber-type air disinfection system. Appl Environ Microbiol 84:e00944-18

Kimura T, Yoshimizu M, Tajima K (1980) Disinfection of hatchery water supply by ultraviolet (U.V.) irradiationII. U.V. susceptibility of some fish pathogenic fungi. Fish Pathol 14:133-137 [in Japanese with English abstract]

Kitancharoen N, Hatai K, Yamamoto A (1997) Aquatic fungi developing on eggs of salmonids. J Aquat Anim Health 9:314-316

Kujundzic E, Matalkah F, Howard CJ, Hernandez M, Miller SL (2006) UV air cleaners and upper-room air ultraviolet germicidal irradiation for controlling airborne bacteria and fungal spores. J Occup Environ Hyg 3: 536-546

Kujundzic E, Hernandez M, Miller SL (2007) Ultraviolet germicidal irradiation inactivation of airborne fungal spores and bacteria in upper-room air and HVAC in-duct configurations. J Environ Eng Sci 6:1-9

Kumar S, Stecher G, Tamura K (2016) MEGA7: molecular evolutionary genetics analysis version 7.0 for bigger datasets. Mol Biol Evol 33:1870-1874

Lefort V, Longueville JE, Gascuel O (2017) SMS: smart model selection in PhyML. Mol Biol Evol 34:24222424

Lévesque CA, De Cock AWAM (2004) Molecular phylogeny and taxonomy of the genus Pythium. Mycol Res 108:1363-1383

Liu Y, de Bruijn I, Jack AL, Drynan K, van den Berg AH, Thoen E, Sandoval-Sierra V, Skaar I, van West P, Diéguez-Uribeondo J, van der Voort M, Mendes R, Mazzola M, Raaijmakers JM (2014) Deciphering microbial landscapes of fish eggs to mitigate emerging diseases. ISME J 8:2002-2014

Miura M, Oono H, Tuchida N, Hatai K, Kiryu T (2005) Control of water mold infection in rainbow trout eggs by using copper fiber. Fish Pathol 40:81-86

Miura M, Hatai K, Tojo M, Wada S, Kobayashi S, Okazaki T (2010) Visceral mycosis in ayu Plecoglossus altivelis larvae caused by Pythium flevoense. Fish Pathol 45:24-30

Noga EJ (1993) Water mold infections of freshwater fish: recent advances. Annu Rev Fish Dis 3:291-304

Ogawa G (2014) Fluctuations in the stock size and return rate, and the damage and recovery from the great East Japan earthquake in hatchery for the chum salmon Oncorhynchus keta in Iwate Prefecture. J North Japan Fish Econ 42:20-23 [in Japanese]

Ota S, Vaulot D, Le Gall F, Yabuki A, Ishida K (2009) Partenskyella glossopodia gen. et sp. nov., the first report of a chlorarachniophyte that lacks a pyrenoid. Protist 160:137-150

Phillips AJ, Anderson VL, Robertson EJ, Secombes CJ, van West P (2008) New insights into animal pathogenic oomycetes. Trends Microbiol 16:13-19

Ronquist F, Teslenko M, van der Mark P, Ayres DL, Darling A, Höhna S, Larget B, Liu L, Suchard MA, Huelsenbeck JP (2012) Mrbayes 3.2: efficient bayesian phylogenetic inference and model choice across a large model space. Syst Biol 61:539-542

Sandoval-Sierra JV, Latif-Eugenin F, Martín MP, Zaror L, Diéguez-Uribeondo J (2014a) Saprolegnia species affecting the salmonid aquaculture in Chile and their associations with fish developmental stage. Aquaculture 434:462-469

Sandoval-Sierra JV, Martín MP, Diéguez-Uribeondo J (2014b) Species identification in the genus Saprolegnia (Oomycetes): defining DNA-based molecular operational taxonomic units. Fungal Biol 118:559-578

Sudova E, Machova J, Svobodova Z, Vesely T (2007) Negative effects of malachite green and possibilities of its replacement in the treatment of fish eggs and fish: a review. Vet Med 52:527-539 
Suzuki S (1960) Ecological studies on the genus Aphanomyces (aquatic fungi) in Japanese lakes. Jpn J Limnol 21:25-31 [in Japanese]

Tambong JT, de Cock AWAM, Tinker NA, Lévesque CA (2006) Oligonucleotide array for identification and detection of Pythium species. Appl Environ Microbiol 72:2691-2706

van den Berg AH, McLaggan D, Diéguez-Uribeondo J, van West P (2013) The impact of the water moulds Saprolegnia diclina and Saprolegnia parasitica on natural ecosystems and the aquaculture industry. Fungal Biol Rev 27:33-42

Vlasenko ML (1969) Ultraviolet rays as a method for the control of diseases of fish eggs and young fishes. Probl Ichthyol 9:697-705

Weisburg WG, Barns SM, Pelletier DA, Lane DJ (1991) 16S ribosomal DNA amplification for phylogenetic study. J Bacteriol 173:697-703

Xu Z, Wu Y, Shen F, Chen Q, Tan M, Yao M (2011) Bioaerosol science, technology, and engineering: past, present, and future. Aerosol Sci Technol 45:1337-1349

Yanong RPE, Erlacher-Reid C (2012) Biosecurity in aquaculture, part 1: an overview. South Reg Aquac Cent 4707:1-16

Publisher's note Springer Nature remains neutral with regard to jurisdictional claims in published maps and institutional affiliations. 